\title{
Heat Stress Mitigation with Fogging System of Anatolian Water Buffaloes
}

\author{
İsrafil Kocaman ${ }^{1, a, *}$, Can Burak Şişman ${ }^{1, b}$, Hüseyin Comert Kurç̣, \\ ${ }^{1}$ Biosystems Engineering Department, Agricultural Faculty, Namık Kemal University, TR-59030 Tekirdağ, Turkey.
} *Corresponding author

A R T I C L I N F O A B S T R A C T

Research Article This research was carried out to investigate the possibilities of removing the heat stress that may occur in Anatolian water buffaloes with a fogging system and to determine the cooling efficiency of the system. In this context, two 24-headed groups were formed among the water buffaloes that were considered to have the same genetic similarities, were born in the same period and have the

Received : 16/06/2021 Accepted : 13/07/2021 same lactation number. One group was housed under controlled shelter conditions (Shelter-I), where the ambient temperature can be controlled, and the other group was housed in existing farmerraising conditions (Shelter-II). The same feed rations were applied to both buffalo groups. The cooling efficiency of the fogging system established in Shelter-I was between $45.6 \%$ and $85.7 \%$ positive. Temperature-Humidity Index values changed between 19.9 and 23.1 in Shelter-I and 19.5 and 26.4 in Shelter-II according to the maximum average data. According to these values, the level of stress in Shelter-II has reached very serious levels and affected the milk yield of buffaloes negatively. The corrected 305-day lactation milk yields were calculated as $1965.4 \mathrm{~kg}$ in Shelter-I

Anatolian water buffalo Temperature stress Cooling efficiency Temperature-Humidity index Animal welfare and $1757.1 \mathrm{~kg}$ in Shelter-II. The differences between all data obtained for Shelter-I and Shelter-II were found statistically significant.

ikocaman@nku.edu.tr ckurc@nku.edu.tr http://orcid.org/0000-0002-3659-3413 http://orcid.org/0000-0002-0187-7993 cbsisman@nku.edu.tr

http://orcid.org/0000-0003-0917-8529

\section{Introduction}

The temperature range in which animals can perform their productive functions in the best way and where they can be most comfortable is defined as 'Comfort Zone' and covers a narrow temperature range. Temperatures within the boundaries of the comfort zone are the optimum temperatures for animals (Mutaf, 2012). As the comfort moves away from the region heat stress that is called thermal stress, occurs in farm animals.

The seasonal effect of temperature stress is manifested in hot and humid regions, especially in the hot summer months. Temperature stress can occur at both high and low temperatures. However, since high temperatures pose more problems, problems that arise with high temperature generally come to mind when it comes to temperature stress.

The effects of temperature stress on the animal and its performance are well defined. With high environmental temperature, rectal temperature rises, feed and energy consumption and milk yield are decreasing. The ambient temperature rises outside the normal limits $\left(5-25^{\circ} \mathrm{C}\right)$ and the increase in relative humidity adversely affects the animal's thermoregulation ability negative. High-yielding animals are more affected by temperature stress than lowyielding animals. Because high yielding animals are metabolically more active and extra heat loading is higher in these animals. To help the animals cope with the heat stress, some managerial arrangements such as canopy, water fogging, shower application, fan fogging should be made. These applications; prevents the animal to load heat from the environment, contributes to the animal's removal of heat from the body by an evaporative way (Gorgulu, 2013).

For water buffaloes, the ambient temperature is more important than normal cattle. The water buffaloes are from the group of homoeothermic animals like other cattle, and their skin (1:6) contains less than one sweat gland than the cattle skin (Borghese, 2005). In addition, the skin of buffaloes is thicker than cowhide and the density of hair on their bodies is considerably lower than that of cattle. While this value is approximately $100-200 / \mathrm{cm}^{2}$ by buffaloes, this value is $1000 / \mathrm{cm}^{2}$ by cattle. This limits heat dissipation and evaporation through perspiration, affects negatively the feed consumption, growth rate, milk production and fertility (Thomas, 2004). 
This research was carried out to investigate the possibilities of removing the temperature stress that may occur in Anatolian water buffaloes with a fogging system and to determine the cooling efficiency of the system. In addition, the effects of the established system on the lactation milk yield and lactation period of the Anatolian water buffaloes were investigated within the scope of the study.

\section{Material and Methods}

Selected pilot region for the research is in Turkey's Trakya part and is connected to Istanbul to Water Buffalo Breeders Association' and conducted a sufficient number of farms with livestock buffalo. The enterprise is located in Çatalca district of Istanbul province. Anatolian water buffaloes in the Mediterranean buffalo group originate from river buffaloes (Sekerden, 2001). Research area is between $41^{\circ} 12^{\prime}$ north latitude and $28^{\circ} 44^{\prime}$ east longitude as geographical location. Its height above sea level is average $119 \mathrm{~m}$. Its climate is a mild climate with the feature of transition between the Black Sea and Mediterranean climates. According to the meteorological records for many years, the annual average temperature is $13.8^{\circ} \mathrm{C}$ and the annual average relative humidity is $84.5 \%$. On the other hand, summer season has great importance for heat stress. According to meteorological records, the average temperature of June, July and August months are $20.6^{\circ} \mathrm{C}$, $22.5^{\circ} \mathrm{C}$, and $22.3^{\circ} \mathrm{C}$, respectively (Anonymous, 2021).

In the selected enterprise, two groups with 24 heads were formed from milking water buffaloes that were born in the same period, whose genetic similarities were considered to be the same, with the same lactation number. The average age at first conception for Anatolian water buffaloes is 608.8 days (approximately 20 months). Lactation times vary between 250-300 days (Soysal, 2009). The Anatolian water buffaloes that formed research groups were in the $4^{\text {th }}$ lactation period, and their ages were between 5.5-6 years. The lactation periods of water buffaloes started in January for both groups. The water buffaloes were milked twice daily once in the morning and once in the night along the lactation period by a portable milking machine. Artificial insemination was applied in the reproduction of water buffaloes. During the research, the same feed rations were applied to both water buffalo groups. One of the water buffalo groups is housed in an environment where the ambient temperature can be controlled (Shelter-I) and the other is housed in the current farmer-growing conditions (Shelter-II). In order to ensure homogeneity in the measurements, the floor area and internal volume per water buffalo was tried to be equalized. Accordingly, the amount of floor area and internal volume per water buffalo is $3.41 \mathrm{~m}^{2}, 12.03 \mathrm{~m}^{3}$ in Shelter-I and 3.37 $\mathrm{m}^{2}$ and $12.15 \mathrm{~m}^{3}$ in Shelter-II, respectively. Both shelters are closed tie-stall type and animals are exposed to natural ventilation. Both shelters are elongated in the east-west direction. There are paddock areas in front of both shelters' southern side. Average weights of water buffaloes were determined as $537.25 \mathrm{~kg}$ by weighing with electronic scales.

In the Shelter-I, a fogging system has been installed to keep the ambient temperature around $25^{\circ} \mathrm{C}$, which is considered the initial temperature or threshold value of the temperature stress. In the established system, the fogging lines were placed in the roof space, at a height of $3.0 \mathrm{~m}$ from the shelter floor, corresponding to the middle of the standing platform. With the help of high pressure electric water pump to the fogging system, clean water passed through the filter system and sprayed to the lines with a pressure of 70-120 bar, from there to the shelter environment with diameters less than 20 microns with the help of $0.5 \mathrm{~mm}$ diameter nozzle. In the system, a nozzle is used for each water buffalo. The operation of the system is automatically controlled with the help of a sensor that can be adjusted according to the temperature or relative humidity placed in the shelter environment. Also, timing adjustment was made on the pump so that the fogging time is 5 seconds and the waiting time is 10 seconds so that the buffaloes are not disturbed by excessive fog. For both water buffalo groups, 24 hours a year, the temperature and relative humidity values of the shelter inside and outside the shelter were measured at intervals of 10 minutes with the help of a thermohygrometer.

In order to evaluate the performance of the fogging system, the temperature was highest in June, July and August in two repetitions, before and after fogging at different times, temperature and relative humidity values were measured remotely with infrared thermometer on the water buffalo surfaces with no direct contact to the animals, and in the shelter environment with a thermohygrometer. Measurements before fogging were done at 12:00 and measurements after fogging were done at 14:00. This time interval was chosen because it is the hottest hours of the day. Three thermohygrometers were used in the measurements as Shelter-I, Shelter-II and outside the shelter. Thermohygrometers were placed in the middle of the shelter to represent the shelter, based on the withers height of the animals.

Equation 1 given in Mutaf (2012) was used to determine the cooling efficiency (CE) of the fogging system established under the Shelter-I conditions. The magnitude of the \% value to be obtained from the equation shows the cooling performance of the system.

$$
\mathrm{CE}(\%)=\left[\left(\mathrm{t}_{\mathrm{di} .}-\mathrm{t}_{\mathrm{di.fog}}\right) /\left(\mathrm{t}_{\mathrm{di}}-\mathrm{t}_{\mathrm{wi}}\right)\right] \times 100
$$

In the equation; where $t_{d i}$ is dry bulb temperature of indoor air $\left({ }^{\circ} \mathrm{C}\right), \mathrm{t}_{\text {di.fog }}$ is dry bulb temperature of indoor air after fogging $\left({ }^{\circ} \mathrm{C}\right)$ and $t_{\text {wi. }}$ is wet bulb temperature of indoor air $\left({ }^{\circ} \mathrm{C}\right)$. The values used in the equation are the values measured in the environment before and after fogging.

The Temperature-Humidity Index (THI), which is used to describe temperature stress in terms of animal welfare, has been calculated separately for both shelters. In calculating the Temperature-Humidity Index, Marai et al. (2001), Equality 2 is used below for buffaloes.

$$
\mathrm{THI}=\mathrm{t}_{\mathrm{d}}-\left[(0.31-0.31 \mathrm{RH}) \times\left(\mathrm{t}_{\mathrm{d}}-14.4\right)\right]
$$

In the equation; $t_{d}$; where is dry bulb temperature $\left({ }^{\circ} \mathrm{C}\right)$ and $\mathrm{RH}$ is relative humidity $(\mathrm{RH}=\mathrm{RH} \% / 100)$. The values used in the equation are the daily minimum, maximum and monthly average values

In evaluating the effects of stress level on animal welfare according to Temperature-Humidity Index value, Marai et al. (2001) the limit values given in Table 1 are taken into consideration. 
Table 1. The relationship between Temperature-Humidity Index and stress level for water buffaloes

\begin{tabular}{c|c}
\hline Temperature-Humidity Index & Stress level \\
\hline$<22.2$ & no \\
$22.2<23.3$ & moderate \\
$23.3<25.6$ & serious \\
$>25.6$ & very serious \\
\hline
\end{tabular}

Table 2. The changes of body surface temperature in the water buffaloes before and after fogging

\begin{tabular}{|c|c|c|c|c|c|c|c|c|}
\hline \multirow[t]{2}{*}{ Months } & \multirow{2}{*}{$\begin{array}{c}\text { Indoor } \\
\text { temperature }\left({ }^{\circ} \mathrm{C}\right)\end{array}$} & \multirow{2}{*}{$\begin{array}{c}\text { Indoor relative } \\
\text { humidity } \\
(\%)\end{array}$} & \multirow{2}{*}{$\begin{array}{c}\text { Ear number } \\
\text { of water } \\
\text { buffalo }\end{array}$} & \multirow[t]{2}{*}{ Iteration } & \multicolumn{4}{|c|}{$\begin{array}{l}\text { Body temperature of different zones } \\
\left({ }^{\circ} \mathrm{C}\right)\end{array}$} \\
\hline & & & & & Head & Neck & Abdomen & Anus \\
\hline \multirow{10}{*}{ June } & \multicolumn{8}{|c|}{ Before fogging } \\
\hline & \multirow{4}{*}{27.0} & \multirow{4}{*}{74.7} & $1(12.14)$ & 1 & 31.8 & 32.6 & 35.5 & 35.9 \\
\hline & & & $2(12.0)$ & 2 & 31.1 & 32.3 & 32.4 & 35.6 \\
\hline & & & $3(38.0)$ & 3 & 31.2 & 30.5 & 33.4 & 35.8 \\
\hline & & & $4(17.85)$ & 4 & 30.7 & 33.1 & 32.7 & 35.6 \\
\hline & \multicolumn{8}{|c|}{ After fogging } \\
\hline & \multirow{4}{*}{24.0} & \multirow{4}{*}{78.3} & $1(12.14)$ & 1 & 27.9 & 30.3 & 32.1 & 33.1 \\
\hline & & & $2(12.0)$ & 2 & 29.2 & 30.3 & 30.1 & 34.3 \\
\hline & & & $3(38.0)$ & 3 & 28.3 & 27.8 & 30.8 & 35.2 \\
\hline & & & $4(17.85)$ & 4 & 29.2 & 30.4 & 31.1 & 34.5 \\
\hline \multirow{10}{*}{ July } & \multicolumn{8}{|c|}{ Before fogging } \\
\hline & \multirow{4}{*}{27.8} & \multirow{4}{*}{64.5} & $1(12.14)$ & 1 & 31.9 & 33.3 & 31.9 & 35.9 \\
\hline & & & $2(12.0)$ & 2 & 32.4 & 33.0 & 33.4 & 36.5 \\
\hline & & & $3(38.0)$ & 3 & 31.0 & 30.7 & 30.9 & 35.4 \\
\hline & & & $4(17.85)$ & 4 & 32.9 & 34.5 & 33.5 & 37.5 \\
\hline & \multicolumn{8}{|c|}{ After fogging } \\
\hline & \multirow{4}{*}{24.9} & \multirow{4}{*}{77.5} & $1(12.14)$ & 1 & 29.0 & 31.0 & 30.2 & 34.6 \\
\hline & & & $2(12.0)$ & 2 & 30.6 & 30.4 & 29.4 & 35.2 \\
\hline & & & $3(38.0)$ & 3 & 27.8 & 28.3 & 29.6 & 34.4 \\
\hline & & & $4(17.85)$ & 4 & 30.5 & 30.2 & 31.5 & 35.8 \\
\hline \multirow{10}{*}{ August } & \multicolumn{8}{|c|}{ Before fogging } \\
\hline & \multirow{4}{*}{28.1} & \multirow{4}{*}{78.0} & $1(12.14)$ & 1 & 31.2 & 34.5 & 35.4 & 37.0 \\
\hline & & & $2(12.0)$ & 2 & 32.5 & 34.4 & 33.2 & 37.3 \\
\hline & & & $3(38.0)$ & 3 & 31.3 & 33.2 & 35.1 & 37.2 \\
\hline & & & $4(17.85)$ & 4 & 33.2 & 34.9 & 34.6 & 37.1 \\
\hline & \multicolumn{8}{|c|}{ After fogging } \\
\hline & \multirow{4}{*}{25.2} & \multirow{4}{*}{85.1} & $1(12.14)$ & 1 & 29.4 & 32.3 & 33.9 & 36.2 \\
\hline & & & $2(12.0)$ & 2 & 30.5 & 32.2 & 31.3 & 36.1 \\
\hline & & & $3(38.0)$ & 3 & 29.6 & 30.3 & 33.5 & 36.7 \\
\hline & & & $4(17.85)$ & 4 & 30.1 & 32.1 & 32.6 & 36.4 \\
\hline
\end{tabular}

In addition, daily milk yield records were kept during the lactation of the water buffaloes, which were selected completely by chance from the groups that were created. The statistical analyses of the research were made according to descriptive statistics and DUNCAN multiple comparison test (Soysal, 2012).

\section{Results and Discussion}

Water buffalo breeding, conservation of biological diversity, in terms of diversification of animal and food sources is of great importance for Turkey. Turkey's next extinction or reduction of natural habitats due to various reasons of water buffalo, water buffalo breeding is carried out in traditional closed type shelters for herd management, ease of maintenance and hosting more animals in the unit area and for a controlled production. In order for water buffaloes to get rid of the negative effects of high temperature, especially in the summer months, cooling pools should be built in these types of enterprises or different cooling systems should be established. Installation of cooling pools may not be appropriate due to space requirements, construction and operating costs and environmental problems that may arise. Alternatively, fogging and cooling systems may be more economical to install and operate. For this purpose, in order to evaluate the performance of the fogging system established in Shelter-I, measurements were made at different points on the animal surface before and after fogging with an infrared thermometer. The data obtained from the measurements are given in Table 2 .

Correlation coefficients between the statistical analysis and the features used in the research are given in Table 3.

When Table 2 is examined for the performance of the fogging system established in Shelter-I within the scope of the research, it is seen that the surface temperature has decreased by $2-3^{\circ} \mathrm{C}$ in the measurements made at different points on the surface of the water buffaloes. Likewise, there was a decrease in the ambient temperature of the shelter around $3^{\circ} \mathrm{C}$, while the relative humidity increased 
as expected. However, the increase in relative humidity is not above the limit values accepted for animal shelters. The increase in relative humidity can be easily eliminated with effective ventilation. The problems observed in terms of temperature stress are important due to both animal welfare and significant decreases in yield characteristics (West, 2003; Hansen, 2007). Turkey's animal shelter in planning the study, is to pay attention to many factors reducing heat stress, water buffalo shelters are mostly made with a temperature control that is based on the breeder experience. However, since the thermal environment in animal shelters directly affects the metabolic heat production and efficiency of the animals and indirectly their health and comfort, it is the most important factor in increasing productivity in animal husbandry. The amount of heat and water vapor produced by the animals in the shelter varies depending on the temperature and humidity in the indoor environment (Mutaf et al. 2004). For this reason, when inhouse thermal environmental control is not sufficient, as a result of the negative effect of heat coercion, effective utilization from genotypic potential decreases and causes loss of efficiency.

The highest correlation coefficient between the statistical analysis and the features used in the study was found to be 0.86 high and positive between the shelter temperature and the head region surface temperature $(\mathrm{P}<0.01)$. A negative and high correlation was found as 0.55 between the shelter relative humidity and the shelter temperature $(\mathrm{P}<0.01)$.

The cooling effectiveness of the fogging system under controlled shelter conditions was calculated using the data obtained from the measurements made in different time periods during the summer season, psychrometric diagram and Equation 1 proposed by Mutaf (2012). The results obtained are given in Table 4.

As seen in Table 4, the cooling efficiency of the fogging system varies between $45.6 \%$ and $85.7 \%$. As the difference between dry and wet temperatures increases, cooling efficiency increases. The higher the percentage values of the calculated cooling efficiency from zero, the higher the performance of the fogging system that was installed (Mutaf, 2012). When the data in Table 2 and Table 4 are evaluated together, a well-planned fogging system will be beneficial in reducing the negative effects of temperature stress that may occur by water buffaloes during extreme heat periods. As Tao and Xin (2003) stated, cooling by fogging is done either by spraying high pressure water into the shelter, cooling the air inside the shelter or by spraying water directly onto the animals. As a result of wetting the body surface by spraying water directly on the body surface of the animal, some of the heat turns into latent heat for the evaporation of the water on the body surface, and consequently, heat coercion is eliminated.

Temperature-Humidity Index values for Shelter-I and Shelter-II were calculated with the help of Equation 2 by using the daily average minimum, maximum and monthly average temperature values of the shelters of the research shelters, measured in the summer and autumn months, and the relative humidity data in the periods when these values were seen. The calculated values are given in Table 5 for Shelter-I and Table 6 for Shelter-II.

When Table 5 is examined for Shelter-I in terms of Temperature-Humidity Index, the index values in the summer and autumn seasons are between 19.9 and 23.1 according to the daily maximum average data and the daily minimum average data, varies between 11.9 and 20.5 and monthly average data varies between 15.9 and 21.8. When the calculated limit values are evaluated according to the scale in Table 1, it shows that the temperature stress is only moderate according to the maximum average data in the summer season and shows that there is no temperature stress in both summer and autumn seasons. The fogging system established in Shelter-I was effective in achieving this result. When Table 6 is examined for the Shelter-II, the Temperature-Humidity Index values in the summer and autumn seasons are between 19.5 and 26.4 according to the daily maximum average data, and the daily minimum average data, varies between 9.6 and 21.6 and according to the monthly average data, it varies between 14.8 and 23.6.

Table 3. The correlation coefficients between indoor temperature, indoor relative humidity and temperature of different body zones and significant test result

\begin{tabular}{|c|c|c|c|c|c|}
\hline & Indoor temperature & Indoor relative humidity & Head & Neck & Abdomen \\
\hline Indoor relative humidity & $-0.55^{* *}$ & & & & \\
\hline Head & $0.86^{* *}$ & $-0.49 *$ & & & \\
\hline Neck & $0.78 * *$ & -0.23 & $0.82 * *$ & & \\
\hline Abdomen & $0.64 * *$ & -0.001 & $0.58 * *$ & $0.70 * *$ & \\
\hline Anus & $0.72 * *$ & -0.07 & $0.77 * *$ & $0.72 * *$ & $0.69 * *$ \\
\hline
\end{tabular}

*P<0.05, **P<0.01;

Table 4. The determination of cooling efficiency of fogging system under controlled shelter conditions

\begin{tabular}{|c|c|c|c|c|c|c|c|}
\hline \multirow[b]{2}{*}{ Months } & \multicolumn{3}{|c|}{ Before fogging } & \multicolumn{3}{|c|}{ After fogging } & \multirow[b]{2}{*}{$\begin{array}{c}\text { Cooling } \\
\text { efficiency } \\
\text { CE }(\%)\end{array}$} \\
\hline & $\begin{array}{c}\text { Dry bulb } \\
\text { temperature } \\
\mathrm{t}_{\mathrm{di}}\left({ }^{\circ} \mathrm{C}\right)\end{array}$ & $\begin{array}{c}\text { Relative } \\
\text { humidity } \\
\phi_{\mathrm{i}}(\%)\end{array}$ & $\begin{array}{l}\text { Wet bulb } \\
\text { temperature } \\
\mathrm{t}_{\mathrm{wi}}\left({ }^{\circ} \mathrm{C}\right)\end{array}$ & $\begin{array}{l}\text { Dry bulb } \\
\text { temperature } \\
\mathrm{t}_{\text {di.fog }}\left({ }^{\circ} \mathrm{C}\right)\end{array}$ & $\begin{array}{l}\text { Relative } \\
\text { humidity } \\
\phi_{\text {i.fog }}(\%)\end{array}$ & $\begin{array}{l}\text { Wet bulb } \\
\text { temperature } \\
\mathrm{t}_{\text {wi.fog }}\left({ }^{\circ} \mathrm{C}\right)\end{array}$ & \\
\hline \multirow{2}{*}{ June } & 27.0 & 74.7 & 23.5 & 24.0 & 78.3 & 21.3 & 85.7 \\
\hline & 27.1 & 68.4 & 22.5 & 25.0 & 77.8 & 22.0 & 45.6 \\
\hline \multirow{2}{*}{ July } & 27.8 & 64.5 & 22.7 & 24.9 & 77.5 & 22.0 & 56.8 \\
\hline & 27.9 & 66.1 & 23.0 & 24.0 & 77.6 & 20.8 & 79.5 \\
\hline \multirow{2}{*}{ August } & 28.0 & 68.0 & 23.4 & 25.0 & 77.0 & 21.8 & 65.2 \\
\hline & 28.1 & 78.0 & 23.8 & 25.2 & 85.1 & 23.0 & 67.4 \\
\hline
\end{tabular}


Table 5. The Temperature-Humidity Index values of Shelter-I

\begin{tabular}{|c|c|c|c|c|c|c|c|c|c|}
\hline \multirow[b]{2}{*}{ Months } & \multicolumn{2}{|c|}{ Daily max. average } & \multicolumn{2}{|c|}{ Daily min. average } & \multicolumn{2}{|c|}{ Monthly average } & \multicolumn{3}{|c|}{ Temperature-Humidity Index } \\
\hline & $\begin{array}{l}\text { temp. } \\
\left({ }^{\circ} \mathrm{C}\right)\end{array}$ & $\begin{array}{l}\mathrm{rh} \\
(\%)\end{array}$ & $\begin{array}{l}\text { temp. } \\
\left({ }^{\circ} \mathrm{C}\right)\end{array}$ & $\begin{array}{l}\mathrm{rh} \\
(\%)\end{array}$ & $\begin{array}{l}\text { temp. } \\
\left({ }^{\circ} \mathrm{C}\right)\end{array}$ & $\begin{array}{l}\mathrm{rh} \\
(\%)\end{array}$ & $\begin{array}{l}\text { Daily } \\
\text { max. }\end{array}$ & $\begin{array}{l}\text { Daily } \\
\text { min. }\end{array}$ & $\begin{array}{l}\text { Monthly } \\
\text { average }\end{array}$ \\
\hline June & 26.6 & 74.6 & 18.8 & 57.2 & 24.5 & 69.4 & 22.8 & 17.5 & 21.4 \\
\hline July & 26.8 & 56.1 & 24.1 & 67.6 & 25.1 & 68.1 & 23.1 & 20.4 & 21.7 \\
\hline August & 26.6 & 75.6 & 23.2 & 52.5 & 25.1 & 73.2 & 22.8 & 20.5 & 21.8 \\
\hline September & 25.7 & 71.7 & 18.7 & 80.2 & 23.0 & 67.7 & 22.2 & 17.4 & 20.3 \\
\hline October & 23.8 & 71.8 & 14.6 & 66.3 & 18.9 & 74.6 & 20.9 & 14.5 & 17.6 \\
\hline November & 22.5 & 64.3 & 10.8 & 77.0 & 16.6 & 74.8 & 19.9 & 11.9 & 15.9 \\
\hline
\end{tabular}

Table 6. The Temperature-Humidity Index values of Shelter-II

\begin{tabular}{l|ccccccccc}
\hline \multirow{3}{*}{ Months } & \multicolumn{2}{|c}{ Daily max. average } & \multicolumn{2}{c}{ Daily min. average } & \multicolumn{2}{c}{ Monthly average } & \multicolumn{2}{c}{ Temperature-Humidity Index } \\
\cline { 2 - 10 } & temp. & rh & temp. & rh & temp. & rh & Daily & Daily & Monthly \\
min. & average \\
June & $\left({ }^{\circ} \mathrm{C}\right)$ & $(\%)$ & $\left({ }^{\circ} \mathrm{C}\right)$ & $(\%)$ & $\left({ }^{\circ} \mathrm{C}\right)$ & $(\%)$ & max. & 23.3 \\
July & 31.7 & 74.8 & 22.2 & 67.4 & 27.2 & 65.1 & 26.4 & 19.8 & 23.5 \\
August & 31.1 & 69.8 & 24.8 & 60.3 & 27.5 & 62.7 & 25.9 & 21.6 & 23.5 \\
September & 31.5 & 72.1 & 23.2 & 65.6 & 27.7 & 69.3 & 26.3 & 20.5 & 23.6 \\
October & 26.5 & 69.5 & 18.8 & 76.8 & 23.3 & 66.9 & 22.8 & 17.4 & 20.5 \\
November & 22.9 & 74.2 & 13.8 & 63.1 & 18.9 & 71.4 & 20.3 & 13.9 & 17.5 \\
\hline
\end{tabular}

Table 7. The lactation lengths and lactation milk yields of the selected Anatolian water buffaloes for the same period of lactation

\begin{tabular}{l|cc|lcc}
\hline \multicolumn{2}{c|}{ Shelter-I } & \multicolumn{3}{c}{ Shelter-II } \\
\hline Ear number & $\begin{array}{c}\text { Lactation length } \\
\text { (day) }\end{array}$ & $\begin{array}{c}\text { Lactation milk } \\
\text { yield }(\mathrm{kg})\end{array}$ & Ear number & $\begin{array}{c}\text { Lactation length } \\
\text { (day) }\end{array}$ & $\begin{array}{c}\text { Lactation milk } \\
\text { yield }(\mathrm{kg})\end{array}$ \\
\hline $1(12.14)$ & 285 & 1701 & $1(7.0)$ & 281 & 1746 \\
$2(12.0)$ & 283 & 1887 & $2(35.0)$ & 278 & 1620 \\
$3(38)$ & 295 & 1906 & $3(27.44)$ & 280 & 1610 \\
$4(17.85)$ & 298 & 2044 & $4(12.10)$ & 280 & 1562 \\
\hline Average & 290.5 & 1884.4 & Average & 280.5 & 1634.6 \\
\hline
\end{tabular}

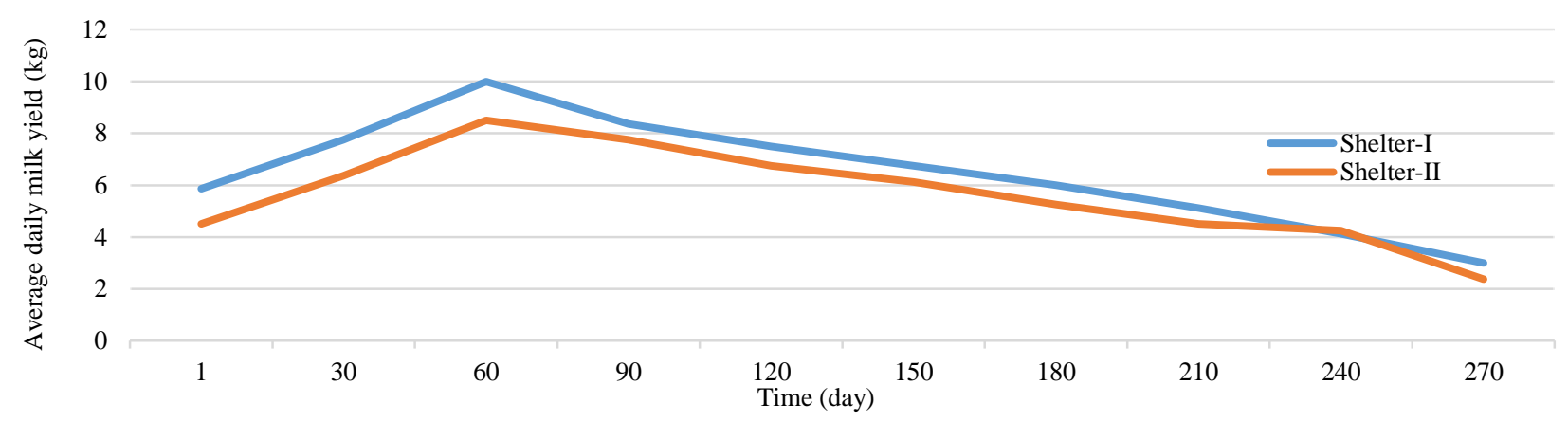

Figure 1. The lactation curves for Shelter-I and Shelter-II

When the calculated limit values are evaluated according to the scale in Table 1 , it is seen that the temperature stress is very serious in comparison with the maximum average data in the summer months and in comparison with the monthly average data. In the fall season only in September, according to the maximum values, there is a moderate temperature stress.

Milk yields of Anatolian water buffaloes were analyzed according to real values and evaluated statistically. Daily milk yield records of groups that were created by randomly choosing among the water buffaloes hosted in Shelter-I and Shelter-II were kept. The lactation times and lactation milk yields of both groups are removed from the daily records and given in Table 7.

The lactation curves obtained from the values observed for the shelters are given in Figure 1.
With the help of the existing correction coefficients stated in Muhammad (2009), the milk yield of water buffaloes has been adjusted according to 305 days. Daily average and 305 days corrected milk yields and significance test results are given in Table 8.

Note: The difference between the averages shown in different letters in the same column was found statistically significant $(\mathrm{P}<0.05)$.

Lactation period and milk yield records of buffaloes hosted in Shelter-II confirm this situation. When Table 7 is analysed, the lactation period of Anatolian water buffaloes changed between 283-298 days by water buffaloes that stay in Shelter-I, and 278-281 days by water buffaloes that stay in Shelter-II. Likewise, lactation milk yields varied between 1701-2044 kg for water buffaloes in Shelter-I and $1562-1746 \mathrm{~kg}$ by water buffaloes in Shelter-II. 
Table 8 . The milk yields of the water buffaloes and significance test results

\begin{tabular}{l|cccc}
\hline \multicolumn{1}{c|}{ Shelter } & $\begin{array}{c}\text { Daily average milk yield } \\
(\mathrm{kg})\end{array}$ & $\begin{array}{c}\text { Milk yield } \\
(\mathrm{kg})\end{array}$ & $\begin{array}{c}\text { Milk yield of 305 days } \\
(\mathrm{kg})\end{array}$ & $\begin{array}{c}\text { Lactation length } \\
(\text { day })\end{array}$ \\
\hline I & $6.47 \pm 0.19^{\mathrm{A}}$ & $1884.4 \pm 70.5^{\mathrm{A}}$ & $1965.4 \pm 73.5^{\mathrm{A}}$ & $290.5 \pm 3.80^{\mathrm{A}}$ \\
II & $5.82 \pm 0.13^{\mathrm{B}}$ & $1634.6 \pm 39.2^{\mathrm{B}}$ & $1757.1 \pm 42.1^{\mathrm{B}}$ & $280.5 \pm 0.64^{\mathrm{B}}$ \\
Overall & $6.14 \pm 0.16$ & $1759.5 \pm 170.2$ & $1861.2 \pm 57.8$ & $285.5 \pm 2.60$ \\
\hline
\end{tabular}

When Table 8 is analysed in terms of corrected values, the daily average milk yield of water buffaloes was found to be $6.47 \mathrm{~kg}$ in Shelter-I and $5.82 \mathrm{~kg}$ in Shelter-II. In terms of corrected 305-day milk yields, it was found as $1965.4 \mathrm{~kg}$ in Shelter-I and $1757.1 \mathrm{~kg}$ in Shelter-II. While average lactation times were 290.5 days in Shelter-I, this value was calculated as 280.5 days in Shelter-II.

\section{Conclusions}

The fogging system established under controlled shelter conditions (Shelter-I) has been found to be an effective way to prevent the heat stress that may occur in Anatolian water buffaloes in the hot summer months. The cooling efficiency of the system is between $45.6 \%$ and $85.7 \%$, and it can be said that it provides a very effective cooling. Temperature-Humidity Index values ranged between 15.9 and 21.8 in Shelter-I according to monthly average data, and 14.8 and 23.6 in Shelter-II. According to the evaluation scale, while the water buffaloes that stayed in Shelter-I do not have a temperature stress, it can be said that there is a serious temperature stress by the buffaloes in Shelter-II. This situation is reflected in the lactation time of water buffaloes and milk yield in lactation. As a matter of fact, while the corrected milk yields of 305 days were $1965.4 \mathrm{~kg}$ in Shelter-I, it was $1757.1 \mathrm{~kg}$ in Shelter-II. Similarly, while average lactation times were 290.5 days in Shelter-I, this value was calculated as 280.5 days in Shelter-II.

\section{Acknowledgement}

This work contains a part of TOVAG 1150602 project supported by TUBITAK. We are grateful to Presidency of TUBITAK for supporting the project.

\section{References}

Anonymous. 2021. Meteorological Data in Catalca District of Istanbul Province. Metorology General Directorate, Ankara.

Borghese A. 2005. Buffalo Production and Research. REU Technical Series, FAO. 67. 1-41.

Gorgulu M. 2013. Heat stress and feeding. Available from: http://www.muratgorgulu.com.tr [Accessed 06 March 2020]

Hansen PJ. 2007. Exploitation of genetic and physiological determinants of embryonic resistance to elevated temperature to improve embryonic survival in dairy cattle during heat stress. Theriogenology. 68: 242-49.

Marai IFM, Ayyat MS, Abd El-Monem UM. 2001. Growth performance and reproductive traits at first parity of New Zealand White Female Rabbits as affected by heat stress and its alleviation under Egyptian Conditions. Tropical Animal Health and Production. 33: 457-62. doi: https://doi.org/ 10.1007/s11250-021-02802-3

Muhammad AK. 2009. The Animal of Future. Idara Matbuat-ESulemani, Lahore, Pakistan.

Mutaf S, Alkan S, Seber N. 2004. Design Principles of Animal Barns in Ecological Agriculture. 1'st International Congress on Organic Animal Production and Food Safety, Istanbul, Turkey, 6-9 May 2004, pp. 212-230.

Mutaf S. 2012. The Climatic Environment and Detection Principles of Animal Barns with Engineering Approach.

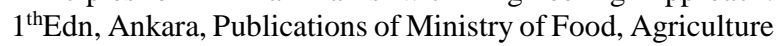
and Livestock. ISBN 978-605-4672-00-4.

Sekerden O. 2001. Cattle Breeding-Water Buffalo Breeding. Hatay, Temizyurek Offset Printing, Publications No 296.

Soysal MI. 2009. Water Buffalo and Its Products Production.

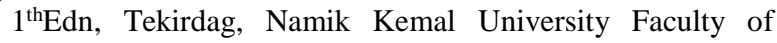
Agriculture Publications. ISBN 978-9944-5405-3-7.

Soysal MI. 2012. The Principles of Biometry. Tekirdag, Namik Kemal University Faculty of Agriculture Publications No 95.

Tao X, Xin H. 2003. Surface wetting and it is optimization to cool broiler chickens. American Society of Agricultural Engineering. 46: 483-490.

Thomas CS. 2004. Milking Management of Dairy Buffaloes. Doctoral thesis, Swedish University of Agricultural Sciences, Swedish.

West JW. 2003 Effects of heat-stress on production in dairy cattle. Journal of Dairy Science 86: 2131-2144. doi: https://doi.org/10.3168/jds.S0022-0302(03)73803-X 